\title{
POSTAVENIE A KLASIFIKÁCIA DRAGU V DIELACH DRAMATICKÝCH UMENÍ
}

\author{
SAMUEL BUCH \\ Ústav literárnej a umeleckej komunikácie, \\ Filozofická fakulta Univerzity Konštantína Filozofa v Nitre
}

\begin{abstract}
Abstrakt: V dejinách dramatických umení je častým úkazom, že postavy jedného pohlavia hrajú herci opačného pohlavia. Tento fenomén sa vyskytuje v kultúrach na celom svete, pričom jeho korene pravdepodobne ležia v spirituálnych praktikách dávnych kultúr. Pre pomenovanie tejto praxe sa v súčasnosti používa pojem drag, vychádzajúci z jazyka polari. So zretelom na teórie spojené s rituálmi, maskou a konceptom liminality sa dá konštatovat', že osoba, ktorá je $\mathrm{v}$ dragu, sa dostáva do liminálnej fázy medzi mužským a ženským svetom. Tento stav jej umožňuje oslobodit sa od rodových stereotypov, ktoré obmedzujú slobodu a autentickost' osobného prejavu. Zámerom príspevku je predstavit historický vývoj dragu a jeho funkciu v ludskej spoločnosti i v prostredí dramatických umení. Problematika dragu v dramatických umeniach bola v odbornej literatúre väčšinou na okraji záujmu. Občasné práce, ktoré sa jej venovali, väčšinou nesledovali rozdielnu povahu jednotlivých prejavov, ale skúmali drag ako vnútorne homogénny fenomén. Táto práca predkladá vnútornú klasifikáciu dragu v dramatických umeniach, $\mathrm{s}$ ambíciou lepšie pochopit jednotlivé prejavy dragu, sledovat ich historický vývoj a ich spoločensko-umeleckú funkciu.
\end{abstract}

Kl'účové slová: divadlo, film, drag, travesty, gender, liminalita, maska

Hranie dramatických postáv hercami opačného pohlavia siaha d’aleko do histórie. $\mathrm{V}$ raných obdobiach európskeho divadla bola táto prax dokonca esenciálnou súčastou dramatického umenia, pretože ženy mali prístup do verejnej sféry zamedzený. Podobné rodové obmedzenia neboli špecifické iba pre našu kultúrnu oblast', vyskytovali sa aj v tradičných divadelných formách iných svetových kultúr. Ako príklad môžeme uviest’ japonské divadlo kabuki či indické tanečné divadlo kathakali. V tejto štúdii sa zameriame na prejavy dragu v dramatických umeniach západnej kultúry, pričom si budeme všímat’ najmä činoherné divadelné umenie a umenie filmové a televízne.

\section{Terminológia}

Pri skúmaní problematiky hrania postáv hercami opačnej pohlavnej či rodovej identity narazíme na nekonzistentnost’ pojmov používaných na jej pomenovanie. V súčasnosti je v česko-slovenskom prostredí obvykle využívaný termín travesty (príp. travesti alebo travestia). I ked’ existuje etymologické opodstatnenie jeho využitia (z talianskeho travestire - prestrojit’ sa), v priebehu rokov sa jeho význam posunul k označeniu parodického diela, pričom pri označení nami skúmanej problematiky má aj určitý hanlivý či znevažujúci podtón. Zároveň dochádza k jeho zámene s podobnými termínmi, ako sú transvestizmus (obliekanie odevu charakteristického pre osoby opačného rodu primárne z dôvodu vnútornej túžby, bez umeleckého zámeru) 
či transgender (stav, pri ktorom rodová identita jedinca nie je v súlade s biologickým pohlavím). Prevažne zahraničná literatúra používa pri pomenovaní dramaticko-umeleckých praktík rodovo-pohlavného prestrojovania aj iné termíny, ako napríklad cross-dressing, female/male impersonator, Hosenrolle a pod. Ich problémom je, že nenašli medzinárodné uplatnenie. Aj v našom prostredí ich originálna podoba komplikuje gramatický aspekt práce a pokusy o preklad prinášajú rôzne komplikácie.

V ostatných desat'ročiach rastie v tomto smere celosvetová popularita angloamerického termínu drag. Anglický lingvista Paul Baker definuje drag ako „oblečenie typické pre jedno pohlavie či rod, nosené niekým, kto sa identifikuje ako pohlavie či rod opačné/ý" “. Používanie termínu drag v tomto kontexte má v angloamerickom prostredí dlhú tradíciu. Prvá písomná zmienka pochádza z roku 1870, ked’ britské noviny Reynold's Newspaper uverejnili pozvánku povzbudzujúcu záujemcov, aby sa „dostavili v dragu, čo znamená muži oblečení do ženských šiat “2. História tohto označenia však siaha ešte pred rok 1870. Patrí k slovám, ktoré tvoria jadro jazyka polari ${ }^{3}$. Korene slova drag vo význame rodového prezliekania nie sú známe. Medzi najčastejšie vysvetlenia patrí jeho využitie na označenie odevov, v ktorých hrali anglickí herci ženské postavy, pričom tieto kostýmy tahali za sebou po zemi (drag - anglicky t’ahat'). Prípadne ide o akronym slov „dressed as a girl“ (oblečený ako dievča). Variabilná povaha utvárania slov v polari neumožňuje spätne určit', ktorá možnost’ je správna. ${ }^{4}$

V priebehu posledných desatročí nadobúda drag celosvetovú obliubu, a to najmä vd’aka televíznej sútaži RuPaul's Drag Race, ktorá vznikla v USA a v súčasnosti existujú jej lokálne variácie v Kanade, Vel'kej Británii, Austrálii, Holandsku, Thajsku atd’. Spoločne s nárastom popularity tohto televízneho formátu stúpa aj celosvetové používanie termínu drag, ktorý rozšíril svoj význam a v súčasnosti ním bývajú označované rozličné umelecké formy, pri ktorých vystupujú umelci v rodovo nonkonformnom úbore. S prihliadnutím na všetky okolnosti sme sa rozhodli priklonit’ k používaniu termínu drag aj v našej práci.

\section{História dragu v západnom dramatickom umení}

Korene dragu v západnom dramatickom umení siahajú do raných období európskej drámy. Jednou z hlavných čŕt antického divadla bola absencia žien-herečiek. Hlavný dôvod spočíval v starovekom spoločenskom postoji k ženám, rozšírenom v stredomorskej oblasti, vyznačujúcom sa patriarchátom s prvkami mizogýnie. Ženskou vlastnostou, ktorá bola v antickom Grécku cenená, bola plachá zdržanlivost’ (sófrosyné), a miesto ženy bolo v prostredí domácnosti. ${ }^{5}$ Ako upozornila anglická

\footnotetext{
${ }^{1}$ BAKER, P. Fabulosa!: The Story of Polari. London : Reaktion Books, 2020, s. 291. Preklady z anglického jazyka S. B.

${ }^{2}$ HALL, J. - BIRKIN, S. - LI, H. - HANS, J. S. Art of Drag. London : Nobrow Ltd., 2020, s. 7.

${ }^{3}$ Išlo o jazyk vytvorený v prostredí homosexuálnej a umeleckej subkultúry, primárne kombináciou angličtiny, románskych jazykov, jidišu, londýnskeho dialektu, backslangu a rýmovaného slangu Cockney. Po skončení policajných perzekúcii voči LGBTI komunite sa polari prestal používat’ a stratil charakter živého jazyka. V súčasnosti ho poznajú a používajú len nadšenci a poslední pamätníci.

${ }^{4}$ BAKER, P. Fabulosa!: The Story of Polari, s. $31-82$.

${ }^{5}$ GALÁN, J. E. Láska a sex ve starém Řecku. Praha : Ikar, 2003, s. 101.
} 
odborníčka na antiku Mary Beard, v raných európskych spoločnostiach existoval diskurz, ktorý nariad’oval ženám mlčanie na verejnosti. Napríklad v Homérovej Odysei posiela Telemachos svoju matku Pénelopé do jej izby, aby sa venovala svojej práci - krosnám a vretenu, zatial' čo „rozhovor bude už starost’ou chlapov“. ${ }^{6}$ Aristofanes v komédii Ženský snem prezentuje myšlienku, že ženy majú problém hovorit’ na vyššej úrovni - to má byt’ doménou mužov.?

Následkom týchto spoločenských postojov mali ženy znemožnený prístup k herectvu, a tak všetky postavy, vrátane ženských, museli hrat’ muži. Zároveň sa už z tohto obdobia zachovali hry, ktoré v rámci deja narábajú s rodovým prestrojením. Príkladom môže byt’ spomenutý Ženský snem od Aristofana, v ktorom sa skupina žien prezlečie za mužov. V originálnom koncepte tak muži-herci hrali ženy, ktoré sú prestrojené za mužov. Tento takpovediac dvojnásobný drag zostal prítomný v dramatickom umení aj počas nasledujúcich storočí. ${ }^{8}$ Další príklad na dragovú zápletku v antickej dráme nachádzame napr. v hre Bakchantky od Euripida, v ktorej boh Dionýzos presvedčí thébskeho krála Penthea, aby sa prezliekol za mainadu, a tak mohol preniknút do skupiny skutočných mainád.

Obmedzenia týkajúce sa prístupu žien do divadelného prostredia pretrvali aj po páde antických štátnych útvarov. Situáciu nezmenil ani nástup renesancie, ktorý inak znamenal pre divadlo obdobie opätovného rozvoja. Všeobecne známe je prostredie anglického divadla, v ktorom muži hrávali všetky postavy, a to až do roku 1661, ked' za vlády Karola II. ženy nadobudli možnost' legálne vystupovat na javisku. Táto profesia však ženám nad’alej prinášala sociálnu stigmu. ${ }^{9}$ Stojí za zmienku, že muži, ktorí sa špecializovali na hranie ženských postáv, nedosahovali rovnakú slávu ako ich kolegovia hrajúci mužské postavy a často umierali mladí, následkom podvýživy a otravy olovom zo silného líčenia. ${ }^{10}$

Na území pevninskej Európy zasiahol do vývoja dramatického umenia vznik kočovných divadelných spoločností a rôznych foriem l'udového divadla, ako napríklad talianskej commedie dell' arte. Ked’že išlo väčšinou o malé divadelné skupiny, takpovediac rodinného charakteru, obsadzovali aj ženské členky skupiny. Existencia týchto skupín urýchlila a ul'ahčila vstup žien do divadelného prostredia v Taliansku, Francúzsku či Španielsku. V ostatných častiach Európy, v ktorých neboli podobné útvary bežné, prebiehal tento vývoj ovel’a pomalšie. ${ }^{11}$

Existencia žien $\mathrm{v}$ hereckej profesii so sebou priniesla útlm potreby dragu v divadle. Aj staršie dramatické texty, pôvodne vytvorené pre čisto mužský súbor, naštudovali pohlavne zmiešané súbory. Samozrejme, prienik žien nebol okamžitý, ale išlo o dlhšie trvajúci proces, odlišný pre jednotlivé krajiny aj pre jednotlivé odvetvia dramatického umenia. Následkom prítomnosti herečiek v súbore prestal drag tvorit’ esenciálnu súčast’ divadla a jeho výskyt sa obmedzil len na určitý okruh hier. Tento stav je dominantný až do súčasnosti.

\footnotetext{
${ }^{6}$ BEARD, M. Ženy a moc-Manifest. Bratislava : Inaque, 2020, s. 18.

${ }^{7}$ Tamže, s. 23.

${ }^{8}$ Tvorí napríklad zápletku filmu Viktor und Viktoria (1933).

${ }^{9}$ GARCIA, L. Gender on Shakespeare's Stage: A Brief History. [online]. [cit. 5.5.2021]. Dostupné na internete: https://www.writerstheatre.org/blog/gender-shakespeares-stage-history/.

${ }^{10}$ DOONAN, S. Drag. London : Laurence King Publishing, 2019, s. 117.

${ }^{11}$ POLÁK, M. Divadlo - jeho cesta dejinami. Bratislava : Perfekt, 2009, s. 44.
} 
Dvadsiate storočie znamenalo dôležitú etapu vo vývoji dragu. V prostredí väčších divadelných foriem zotrvával $\mathrm{v}$ tomto ohl'ade status quo nastolený $\mathrm{v}$ predchádzajúcich storočiach. Rozvoj dragu umožnili najmä malé divadelné formy, vznik filmu i vlastný vývoj mimo prostredia dramatického umenia a jeho spojenie s LGBTI komunitou. Na začiatku storočia bol drag bežnou súčastou prevažne komických alebo hudobných výstupov v kabaretoch, anglických music halloch či amerických vaudeville predstaveniach. V tomto prostredí ho dokumentujú aj filmy z prvej polovice storočia, napríklad nemecký film Viktor und Viktoria (1933) či československý film Holka nebo kluk? (1938).

V dvadsiatych rokoch 20. storočia bola na území USA nastolená prohibícia, ktorá, paradoxne, viedla k vzniku nelegálnych podnikov ponúkajúcich alkohol. Pre zábavu návštevníkov boli $\mathrm{v}$ týchto podnikoch organizované kabaretné vystúpenia. Podniky orientované na homosexuálnu klientelu často zamestnávali zabávačov v dragu či mužov imitujúcich femininitu pre pobavenie publika. V tomto období, označovanom ako Pansy Craze, stúpla popularita podobných zabávačov ako nikdy predtým a americké noviny (napr. Variety) informovali, že trend sa rozšíril aj do Paríža či Berlína. ${ }^{12}$ Pansy Craze sú spoločne s tradíciou dragových bálov, ktoré sa v USA organizovali už v 19. storočí13, jedným z hlavných koreňov súčasného prepojenia dragu s LGBTI komunitou. Bály zároveň umožnili dragovým umelcom vykonávat’ drag nezávisle od divadelného prostredia, čo vyústilo do zrodu tzv. dragových královien a dragových králov. ${ }^{14}$

Dragoví králi a královné vo svojej umeleckej činnosti využívajú mnohé prostriedky divadelného prostredia - výrazné líčenie, parochne, nápadné kostýmy; svojmu alter egu taktiež často dávajú originálne meno. Od šest’desiatych rokov 20. storočia podobu subkultúry dragových králov a najmä král'ovien ovplyvnili špeciálne sútaže krásy organizované po celých Spojených štátoch LGBTI aktivistom Jackom Doroshowom, vystupujúcim pod menom Flawless Sabrina, a vznik skupín, tzv. Houses $^{15}$, obvykle zakladaných dragovou král'ovnou a jej partnerom ako útočisko LGBTI mládeže bez domova a priestor na vystupovanie. Formy dragového umenia, ktoré sa vykryštalizovali mimo sféry dramatického umenia, sa v druhej polovici 20. storočia vracajú do prostredia divadla a filmu a vytvárajú možnosti použitia dragu, aké sa predtým $\mathrm{v}$ dramatických textoch neobjavovali.

\section{Drag ako maska}

Je zrejmé, že drag je v dramatickom aj v bežnom živote určitou formou masky. Aby mohol umelec stvárnit’ osobu opačného pohlavia, využíva širokú škálu prostriedkov upravujúcich zovňajšok, napr. líčidlá, parochne, odev, lepiacu pásku, vypchávky, korzety a iné. Kulturológ Vít Erban vo svojej práci Maska a tvář popri iných cituje muzikológa Milana Munclingera, podla ktorého je maskou v hre všetko, čo

\footnotetext{
${ }^{12}$ HALL, J. - BIRKIN, S. - LI, H. - HANS, J. S. Art of Drag, s. 41.

${ }^{13}$ Tamže, s. 25.

${ }^{14}$ Drag queen je osoba obvykle mužského pohlavia, ktorá používa prostriedky ženského genderu v umeleckej činnosti. Drag king je osoba obvykle ženského pohlavia, ktorá používa prostriedky mužského genderu na účely umeleckej činnosti.

${ }^{15}$ House - vo význame dom, ale aj dynastia. Medzi najstaršie patria House of LaBeija, House of Xtravaganza a i.
} 
je na hercovi viditel'né, všetko, vd’aka čomu sa herecky premieňa na inú postavu. ${ }^{16}$ Sinologička L’ubica Obuchová považuje za masku každú zmenu tváre, ktorá upraví vzhl'ad jej nositel'a a dodá mu alternatívnu identitu. ${ }^{17}$ Využívanie masiek má dlhodobú históriu, podobne ich uplatnenie v dramatických umeleckých formách. Masky predstavujú širokú škálu objektov - od neživých až po živé alebo nadprirodzené bytosti. Pri určovaní toho, čo zobrazuje, môžeme drag považovał’ za masku rodovú: osoba v dragu totiž prijíma a performuje charakteristiky prisudzované osobám opačného rodu. Podl’a Erbana sa väčšina autorov zhoduje na tom, že maska človeka oslobodzuje. ${ }^{18}$ Hlavný ciel' masky tak spočíva v rozostrení identity nositel'a, pričom tento jav sa prejavuje v dvoch rovinách - vnútornej sebareflexívnej (Vd’aka maske môžem byt’ kýmkolvek.) a vonkajšej, pri reflexii pozorovatel'om (Neviem, kto sa skrýva pod maskou.).

Podla teórií rodovej performativity pôsobia na každého jedinca spoločenské imperatívy, ktoré na základe jeho pohlavia určujú, akým spôsobom sa má správat'. Ked' osoba praktikuje drag, spochybňuje tým spoločensky proklamovanú esenciálnost’ rodových rol. V spoločnosti, ktorá primárne uznáva iba existenciu dvoch rodov, pričom ich stotožňuje či aspoň nerozlučne prepája s pohlavím, presúva drag jednotlivca do tzv. liminálnej oblasti, ktorú John Emigh, ako spomína vo svojej publikácii Erban, definuje ako obdobie, v ktorom sú kontinuita a zmena, minulost' a budúcnost' držané v nelahkej rovnováhe, na prahu medzi starým a novým. ${ }^{19}$ Nositel’ dragu sa nachádza medzi dvoma svetmi, mužským a ženským: jeden z nich zanechal popretím rodových imperatívov diktovaných spoločnostou, no plnohodnotnému vstupu do druhého bráni jeho biologicky definovaná telesnost'. Z dôvodu existencie rodovej liminality tvorí crossdressing súčast’ magických a kultových praktík viacerých kultúr. $\mathrm{V}$ tejto liminálnej oblasti následne dochádza $\mathrm{k}$ zjednoteniu protikladov mužského a ženského, určité „,coincidentia oppositorum“, ako o ňom píše Mircea Eliade v diele Méphistophélès et l'androgyne $(1962)^{20}$. Osoby, ktoré sa psychicky nachádzajú v tomto stave, môžu následne konat' slobodne, bez rodových stereotypov, ktoré dovtedy znemožňovali slobodu ich sebavyjadrenia.

Spirituálny až liečitel’ský rozmer dragu presahuje aj do niektorých diel dramatického umenia, v ktorých je postava v dragu katalyzátorom kladnej spoločenskej zmeny. Tak je to napríklad vo filme To Wong Foo (1995), v ktorom skupina dragových královien pozitívne ovplyvní život obyvatelov malého mesta. Umelec vystupujúci ako dragová královná pomôže matke s dcérou z drogových problémov vo filme $\mathrm{Ho}$ liday Heart ${ }^{21}$ (2000), zachráni pred krachom továreň na topánky vo filme Kinky Boots 22 (2005) či zmení pomery na škole vo filme Hurricane Bianca ${ }^{23}$ (2016).

\footnotetext{
${ }^{16}$ ERBAN, V. Maska a tvár̆. Praha : Malá skála, 2010, s. 124.

${ }^{17}$ OBUCHOVÁ, L. Maska, kostým a lidové divadlo. Praha : Česká orientalistická společnost, 2001, s. 7.

${ }^{18}$ ERBAN, V. Maska a tvár̆, s. 181.

${ }^{19}$ Tamže, s. 137.

${ }^{20}$ Práca vyšla aj v českom preklade: ELIADE, M. Mefisto a androgyn. Praha : Oikoymenh, 1997.

${ }^{21}$ USA, 2000, réžia Robert Townsend.

${ }^{22}$ USA, 2005, réžia Julian Jarrold.

${ }^{23}$ USA, 2016, réžia Matt Kugelman.
} 


\section{Náčrt klasifikácie dragu v dramatickom umení}

Doterajšie odborné texty venované dragu v oblasti dramatických umení nahliadali na problematiku ako na homogénny problém. Pri štúdiu relevantnej literatúry sme s výnimkou pokusov o chronologické zmapovanie nenarazili na výraznejšie snahy o objavenie určitej vnútornej štruktúry tohto fenoménu. Z takého zovšeobecňujúceho postoja následne vyplýva nemožnost̉ bližšieho skúmania jednotlivých foriem. Čerpajúc inšpiráciu z myšlienok štrukturalizmu a na základe štúdia diel dramatických umení obsahujúcich prvky dragu navrhujeme ich podrobnejšiu klasifikáciu na jednotlivé podkategórie. Ked’že v rámci divadelnej a audiovizuálnej tvorby existuje podobný prístup k využívaniu dragu, čerpáme informácie z diel oboch skupín, pričom nadobudnuté poznatky majú potenciál pozitívne podporit’ výskum oboch oblastí.

Diela dramatických umení, v ktorých sa vyskytujú dragové prvky, môžeme rozdelit’ do troch hlavných skupín:

1. postava v dragu - postava sa počas deja prestrojí za osobu opačného pohlavia;

2. herec v dragu - herec alebo herečka hrá postavu esenciálne opačného pohlavia;

3. diela s transgender tematikou.

Všetky tri kategórie môžeme delit’ na užšie vymedzené podkategórie. Hlavným faktorom, ktorý odlišuje jednotlivé podskupiny, je prvok motivácie. Prvú skupinu delí na podskupiny motivácia, ktorú dal autor diela postave, aby si drag v rámci deja obliekla. Druhú skupinu delí motivácia režiséra alebo inej osoby zodpovednej za obsadenie, ktorá viedla k tomu, aby postavu hrala osoba opačného pohlavia. Motivácie postáv alebo autorov pritom nemusia byt’ jednostranne zamerané, diela môžu vykazovat’ kombináciu viacerých motivácií v rozličných variáciách. Diela s transgender tematikou tvoria skupinu, ktorá sa nachádza na okraji skúmanej problematiky. Do práce o dragu ju zarad’ujeme z dôvodu, že postavy v dielach sú najčastejšie stvárňované cisgender ${ }^{24}$ umelcami, ktorí s hranou postavou zdiel'ajú bud' biologické pohlavie alebo sociálny rod.

\section{Postava v dragu}

Spoločným prvkom diel spadajúcich do tejto skupiny je, že herec hrá postavu, ktorá s ním má zhodné pohlavie, avšak v rámci deja sa z určitého dôvodu oblečie do dragu. Pre staršie diela bola typická dočasná povaha prestrojenia, pričom odhalenie pravej identity bolo častou súčastou rozuzlenia príbehu. V prípade novších diel môže existovat’ drag ako permanentná alebo semipermanentná súčasť života postavy. Rôzne motivácie, ktoré vedú postavu k použitiu dragu, delia túto kategóriu na špecifické podkategórie:

a) ohrozenie - postava sa následkom životných okolností ocitla v bezprostrednom ohrození; aby unikla pozornosti prenasledovatel’ov, prestrojí sa za osobu opačného pohlavia. Podstata tohto prestrojenia vychádza z prístupu, akým západná spoločnost’ vníma vztah pohlavia a rodu. Tieto dva aspekty osobnosti boli dlhodobo stotožňované, preto osoba, ktorá sa prezentuje určitými rodovými charakteristikami, bude považovaná za osobu pohlavia, ktoré zodpovedá týmto charakteristikám. Postava

\footnotetext{
${ }^{24}$ Cisgender - osoba, ktorej rodová identita sa zhoduje s jej biologickým pohlavím. Opak slova transgender, vzniknutý vypožičaním z chemickej terminológie.
} 
obvykle zanechá drag, ked' je odhalená alebo ohrozenie pominulo. Príkladom na túto podkategóriu je americká komédia Niekto to rád horúce ${ }^{25}$ (1959). Hlavní hrdinovia sú svedkami mafiánskej vraždy - aby ušli pred mafiou, prezlečú sa za jazzové muzikantky Daphne a Josephine. Ďalším príkladom je pol’ský sci-fi film Sexmisia ${ }^{26}$ (1983), v závere ktorého sa divák dozvie, že postava Excelencie bola mužom v ženskom prestrojení, ktorý sa obával kastrácie zo strany čisto ženskej spoločnosti.

b) podvod - postava sa prestrojí za osobu opačného pohlavia s úmyslom podvodu. Benefit, ktorého vidina motivuje podvod, tvoria najmä peniaze alebo iná forma zisku. Príkladom tohto typu je československá komédia Holka nebo kluk? (1938, réžia Vladimír Slavínsky), kde hlavná postava Ada Bartů využije drag, v ktorom vystupuje v kabarete, aby si získala priazeň bohatého strýka, ktorý je následkom neúspešných manželstiev nepriatel'om žien.

c) žart alebo gag - postava sa preoblečie za osobu opačného pohlavia za účelom žartu alebo vizuálneho gagu. S takýmto úmyslom bol drag použitý napr. v epizóde amerického seriálu All in the Family s názvom Beverly Rides Again ${ }^{27}$. Hlavné postavy - rodinu Bunkerovcov - navštívi imitátor žien Beverly LaSalle, ktorého člen rodiny Archie presvedčí, aby sa vydával za ženu v rámci žartu, ktorého terčom je Archieho kamarát Pinky Peterson. Dragový gag je častým v prípade komických seriálov, vrátane animovaných, ako je napríklad Looney Tunes a d’alšie.

d) náplň práce - postava sa oblečie do dragu v rámci výkonu svojej pracovnej činnosti, prípadne aby získala pracovnú pozíciu, ktorá bola pre ňu za pôvodných okolností nedostupná. Príkladom tohto typu je nemecký film Viktor und Viktoria (1933, réžia Reinhold Schünzel) a jeho neskoršie spracovania. ${ }^{28}$ Hlavná predstavitel'ka Susanne je herečkou, neúspešne sa pokúšajúcou nájst’ si zamestnanie. Aby zachránila živobytie svojmu zdravotne indisponovanému priatelovi Viktorovi, súhlasí s vystupovaním v kabarete ako „imitátor žien“ Monsieur Viktoria. Úspech, ktorý zožne, ju privedie k tomu, aby predstierala, že je muž, ktorý profesijne imituje ženy. Ďalším príkladom je americký film Tootsie ${ }^{29}$ (1982), v ktorom má herec Michael Dorsey problém nájst’ si prácu. V zúfalstve sa zúčastní na konkurze v ženskom prestrojení a získa úlohu v televíznom seriáli.

Podskupinu tejto kategórie tvorí značne špecifický, no napriek tomu sa opakujúci prípad, ked’ je drag využitý ako súčast’ policajnej akcie. Policajt (alebo príslušník podobnej bezpečnostnej zložky, napr. armády či tajnej služby) sa prestrojí za osobu opačného pohlavia, pričom hlavným dôvodom takéhoto prestrojenia je nevzbudit pozornost' sledovaného subjektu. Známymi snímkami sú napr. Agent v sukni ${ }^{30}$ (2000) či Niekto to rád blond ${ }^{31}$ (2004). Napriek tomu, že tieto príklady pochádzajú z relatívne nedávnej doby, myšlienka využit’ drag v policajnom prostredí nie je $\mathrm{v}$ dramatických umeniach nová, podobnú zápletku má napr. skeč Undercover Cops ${ }^{32}$ odvysielaný v roku 1972 v rámci programu The Carol Burnett Show.

\footnotetext{
${ }^{25}$ V origináli Some Like It Hot. USA, 1959, réžia Billy Wilder.

${ }^{26}$ V origináli Seksmisja. Pol’sko, 1983, réžia Juliusz Machulski.

${ }^{27}$ All in the Family (1971 - 1979), ide o ôsmu epizódu siedmej série.

${ }^{28}$ Napr. Victor und Victoria (1957); Victor/Victoria (1982) a i.

${ }^{29}$ USA, 1982, réžia Sydney Pollack.

${ }^{30} \mathrm{~V}$ origináli Big Momma's House. USA, 2000, réžia Raja Gosnell.

${ }^{31}$ V origináli White Chicks. USA, 2004, réžia Keenen Ivory Wayans.

${ }^{32}$ The Carol Burnett Show - sezóna 5, epizóda 21, rok odvysielania 1972.
} 
e) dosiahnutie nedosiahnutel’ného - postava v dramatickom diele využije drag, aby získala prístup do priestoru, ktorý je z určitých dôvodov zakázaný osobe jej pohlavia či sociálneho statusu. Napríklad v československom filme Venoušek a Stázička (1939, réžia Čeněk Šlégl) sa postava Venouška prezlečie za dievča, aby mohla trávit’ čas osamote so Stázičkou, pred jej otcom následne vystupuje v úlohe kamarátky. $\mathrm{V}$ iných prípadoch sa napríklad muž preoblečie za ženu, aby prenikol do háremu či ženského kláštora; žena sa preoblečie za muža, aby mohla vstúpit’ do armády ${ }^{33}$ či sveta mužskej náboženskej hierarchie ${ }^{34}$ a i.

Postava môže použit drag aj na to, aby dosiahla výhody, ktoré sú následkom rodových stereotypov neprístupné osobe jej pohlavia. Táto situácia sa vyskytuje najmä v spojitosti so ženskými hrdinkami, ktoré v prestrojení za muža mohli nadobudnút výhody osobnej slobody. Vplyvom šírenia emancipácie žien je v moderných dielach tento typ na ústupe, viac sa vyskytuje v historických dielach. Napríklad v hre Carla Goldoniho Sluha dvoch pánov sa Beatrice Rasponi prestrojí za svojho zosnulého brata Federica, aby mohla bez dozoru odíst' z Turína a v Benátkach hladat’ svojho snúbenca. Podobne koná postava Violy v hre Williama Shakespeara Večer trojkrálový, ked’ sa vydáva za Sebastiána.

f) imitovanie, cosplay - postava v rámci deja imituje populárnu osobnost’ opačného pohlavia. $V$ rámci dramatického diela tvoria priestor pre tento typ dragu maškarné plesy, Halloween či výstupy imitátorov, ktoré sú súčastou deja. Výstup imitátorky mužov sa nachádza napr. na začiatku filmu Smrt’ lorda Edgzara ${ }^{35}$ (2000), imitátor žien Jim Bailey v prestrojení za komičku Phillis Diller zase vystupuje v americkom sitkome Here's Lucy ${ }^{36}$.

g) forma životného štýlu - charakterovou črtou postavy je, že žije rodovo nonkonformným životným štýlom a drag nemá explicitnú motiváciu. Tento typ môžeme v dramatických umeniach považovat’ za pomerne nový prvok. Vznikol najmä vd’aka vývoju, ktorý drag zaznamenal mimo divadla v 20. storočí, v prostredí dragovej subkultúry. Postavy performujúce drag ako formu „bežného“ odevu sú najmä dragové král'ovné a králi. Napríklad vo filme To Wong Foo, Thanks for Everything! Julie Newmar $^{37}$ (1995) trojica dragových král'ovien cestuje do Hollywoodu, pričom sú v dragu po väčšinu trvania filmu. Rovnako vystupuje v dragu postava doktora Frank-N-Furtera v kultovom muzikáli The Rocky Horror Picture Show ${ }^{38}$ (1975).

h) psychická porucha - postava sa prezlieka za osobu opačného pohlavia následkom psychického ochorenia, ktorým trpí. Najznámejším príkladom je pravdepodobne postava Normana Batesa z filmu Psycho ${ }^{39}$ (1960), o ktorom sa divák v závere dozvie, že sa prezlieka za svoju dávno mŕtvu matku. Podobné prípady sa nachádzajú vo filmoch Mlčanie jahniat ${ }^{40}$ (1991) či Sleepaway Camp ${ }^{41}$ (1983). Stojí za pozornost', že vo všetkých troch zmienených snímkach ide o mužov-vrahov prezliekajúcich sa za

\footnotetext{
${ }^{33}$ Dramatické spracovania čínskej balady o Mulan z obdobia dynastie Severný Wei (386 - 535 n. 1.).

${ }^{34}$ Americký film Yentl (1983) či nemecký film Die Päpstin (2009).

${ }^{35}$ V origináli Lord Edgware Dies. Vel'ká Británia, 2000, réžia Brian Farnham.

${ }^{36}$ Konkrétne ide o deviatu epizódu piatej série. Sitkom Here's Lucy sa vysielal v rokoch 1968 - 1974.

${ }^{37}$ U nás uvádzaný pod problematickým názvom Traja muži v negližé. USA, 1995, réžia Beeban Kidron.

${ }^{38}$ USA, 1975, réžia Jim Sharman.

${ }^{39}$ USA, 1960, réžia Alfred Hitchcock.

${ }^{40}$ V origináli Silence of the Lambs. USA, 1991, réžia Jonathan Demme.

${ }^{41}$ USA, 1983, réžia Robert Hiltzik.
} 
ženy, z čoho by sa dalo vyvodzovat’ napojenie týchto diel na starý diskurz stotožňujúci rodovú nonkonformitu, homosexualitu a transgender so psychickou poruchou, ktorý takýchto jedincov prezentuje ako hrozbu pre spoločnost'.

Nasledujúce dve podkategórie zatial' existujú viac-menej v hypotetickej rovine, ked’že nie sú vykryštalizované adekvátne príklady z dramatickej umeleckej praxe. Pohl'ad na súčasný vývoj ale naznačuje, že v blízkej budúcnosti sa tieto prípady premietnu aj do diel dramatického umenia.

i) edukácia - použitie dragu v rámci komunikovania obsahu edukatívnej povahy.

j) aktivizmus - následkom historického vývoja je umenie dragu prepojené s LGBTI komunitou, pričom viaceré skupiny využívajú drag ako súčast’ svojho aktivizmu a spoločenského protestu. Najznámejšou organizáciou sú The Sisters of Pepretual Indulgence ${ }^{42}$, ktorej členovia a členky sa od roku 1979 venujú LGBTI aktivizmu, charitatívnym akciám a boju proti HIV/AIDS.

\section{Herec v dragu}

Na rozdiel od podkategórií menovaných v prvej skupine charakterizuje druhú skupinu skutočnost', že drag nie je súčastou deja dramatického textu. Herec alebo herečka opačného pohlavia sú na stvárnenie postavy vybratí na základe vol'by režiséra alebo osôb zodpovedných za obsadenie. V rámci tejto kategórie teda nesledujeme motivácie, ktoré mala postava v príbehu, ale motivácie, ktoré mali osoby zodpovedné za obsadenie herca/herečky opačného pohlavia na stvárnenie danej postavy.

a) spoločenský imperatív - pravdepodobne najstarší typ. Jeho jadro spočíva v spoločenských postojoch, ktoré zakazujú divadelné vystupovanie jedincom určitého rodu alebo pohlavia. Tieto imperatívy sa najčastejšie vztahujú na vystupovanie žien, následkom čoho sú všetky postavy hrané osobami jedného pohlavia. Vplyv emancipácie obvykle spôsobuje zánik tejto kategórie.

b) tradícia - určitá postava v konkrétnom diele je hraná hercom v dragu na základe obvykle nepísanej tradície. Príkladom môžu byt̉ neskoršie naštudovania komediálneho filmu Hairspray ${ }^{43}$ (1988). Vo filme Johna Watersa bol do postavy Edny Turnblad obsadený herec Harris Glenn Milstead, známy najmä vd’aka svojmu dragovému alter egu - Divine. ${ }^{44}$ Hairspray bol neskôr adaptovaný na muzikál na Broadwayi, pričom do postavy Edny Turnblad bol opät obsadený herec v dragu, ako spomienka Divine, čo sa následne stalo pravidlom pre všetky neskoršie spracovania tohto dramatického textu. V nasledujúcich rokoch hrali postavu Edny Turnblad napr. Harvey Fierstein, Michael Ball či John Travolta. Na Slovensku naštudovalo muzikál divadlo Nová scéna (2014), spomínanú úlohu v alternácii stvárnili Peter Sklár a Jevgenij Libezňuk.

c) absencia príslušníkov jedného z pohlaví v súbore - v prípade menších hereckých súborov môže pri naštudovaní diela nastat’ situácia, že zbor nemá dostatok hercov potrebného pohlavia na obsadenie všetkých úloh. Pragmaticky môžu byt๋ dané postavy obsadené osobami opačného pohlavia. Napríklad v tvorbe britskej komediálnej skupiny Monty Python pozostávajúcej zo šiestich mužských členov bolo ob-

\footnotetext{
${ }^{42} \mathrm{~V}$ preklade Sestry perpetuálnej indulgencie alebo Sestry neprestajných odpustkov/pôžitkov.

${ }^{43}$ USA, 1988, réžia John Waters.

${ }^{44}$ Angažovanie Harrisa Glenna Milsteada do tejto postavy bolo výsledkom ich dlhodobej spolupráce s Johnom Watersom. Herec v rovnakom roku zomrel, ide o jeho posledný film.
} 
vyklé, že hrávali aj ženské postavy, často označované ako pepperpots - koreničky ${ }^{45}$. Rovnako sa tento typ vyskytuje aj v prípade väčších súborov, ktoré sú explicitne rovnako pohlavné, ako napríklad japonský ženský súbor Takarazuka Kagekidan ${ }^{46}$.

d) prilákanie pozornosti verejnosti - drag so sebou niesol auru niečoho neobvyklého, ktorú tvorcovia využívali aj na prilákanie pozornosti širšej verejnosti. Príkladom je hra L'Aiglon z roku 1900, napísaná pre herečku Sarah Bernhardtovú, ktorá v nej stvárnila postavu Napoleona II.

e) snaha vystihnút povahovo-anatomické vlastnosti postavy - dramatická postava sa vyznačuje charakteristikami, ktoré pomáha zvýraznit’ jej obsadenie osobou opačného pohlavia. Príkladom môže byt’ obsadenie herca Georgija Mil'ara do postavy Baby Jagy v ruskom filme Mrázik ${ }^{47}$ (1964). Mužské anatomické vlastnosti podčiarkli drsnost' postavy a defeminizovali ju. Priliehavejšia anatómia zohráva úlohu aj pri obsadzovaní chlapčenských postáv herečkami. Chlapčenskou postavou, pri ktorej je to bežnou praxou, je napríklad Peter Pan.

f) snaha naznačit príbuzenskú podobnost' - táto podkategória sa obvykle vyskytuje v rámci dvojroly, v ktorej umelec stvárňuje jednu postavu rovnakého a druhú postavu opačného pohlavia, pričom medzi postavami je príbuzenský vztah. Príkladom je film Jack a Jill ${ }^{48}$ (2011), v ktorom stvárnil Adam Sandler postavy súrodencov Jacka a Jill. Rovnako v televíznom seriáli Are You Being Served? (1972) zobrazil herec John Inman postavu pána Humphriesa aj postavu jeho matky. Takýto postup vytvorí príbuzenskú podobnost’ medzi postavami a zároveň zvýrazní komický aspekt diela.

\section{Diela s transgender tematikou}

Termínom transgender sa označujú osoby, ktorých rodová identita sa nezhoduje s ich biologickým pohlavím. I ked' v prípade týchto osôb de facto nejde o drag, v práci venovanej tomuto fenoménu $\mathrm{v}$ dielach dramatického umenia ich musíme spomenút preto, že transgender postavy obvykle stvárňujú cisgender herci, preto je ich rodová perfomancia $\mathrm{v}$ týchto dielach $\mathrm{v}$ podstate dragom. Vychádzajúc $\mathrm{z}$ tejto premisy, hranie transgender postáv transgender hercami ako také nekvalifikuje dramatické dielo do sféry diel s prvkom dragu. V snahe o štrukturalizáciu tejto kategórie môžeme určit’ dve podskupiny:

a) transgender coming out a tranzícia - pre dramatické diela tohto typu je obvyklé, že v úvode je postava prezentovaná v súlade s rodom, ktorý vychádza z jej biologického pohlavia, avšak v následku uvedomenia si vlastnej odlišnosti začína prijímat' charakteristiky opačného rodu, ktorý zodpovedá jej vnútornej rodovej identite. Pravdepodobne najznámejším príkladom je film Dánske dievča ${ }^{49}$ (2015). Dej sleduje skutočný príbeh dánskeho maliara Einara Wegenera ${ }^{50}$, ktorý si v dôsledku životných

\footnotetext{
${ }^{45}$ Termín zavedený členmi súboru Monty Python. Koreničky boli ženy v domácnosti stredného veku, hrané členom súboru v dragu. Charakterizovali ich škriekajúci falzet a komické priezviská. Názov sa odvodzuje od vysokého štíhleho tvaru koreničky.

${ }^{46} \mathrm{~V}$ preklade Takarazuka Revue.

${ }^{47}$ V origináli Mopoзкo. ZSSR, 1964, réžia Alexandr Rou.

${ }^{48}$ V origináli Jack and Jill. USA, 2011, réžia Dennis Dugan.

${ }^{49}$ V origináli The Danish Girl. USA, 2015, réžia Tom Hooper.

${ }^{50}$ Lili Elbe/Einar Wegener (1882 - 1931) bola jednou z prvých trans žien, ktoré podstúpili medicínsku tranzíciu. Zomrela v roku 1931 následkom infekcie zapríčinenej transplantáciou maternice.
} 
udalostí uvedomí svoju odlišnú rodovú identitu, následne prechádza medicínskou aj legislatívnou tranzíciou a stáva sa ženou Lili Ilse Elvenes.

b) postava po tranzícii - v dramatickom diele sa vyskytuje transgender postava. Vzhl'adom na to, že jej coming out aj tranzícia už prebehli, postava v priebehu deja neprechádza z jedného rodu do druhého. Ked’že doposial' je obsadzovanie transgender hercov skôr výnimkou než pravidlom, tieto úlohy obvykle hrajú cisgender herci, pričom na výber sa núkajú dve možnosti: postava je hraná osobou, ktorá s ňou zdiel’a biologické pohlavie (napríklad vo filme Dobrodružstvá Priscilly, královnej púšte z roku 1994 hral transženu Bernadette herec Terence Stamp), alebo je postava zverená umelcovi, ktorý s ňou zdiel'a rodovú identitu (vo filme Transamerica ${ }^{52}$ z roku 2005 hrala úlohu transženy Sabriny Osbourne herečka Felicity Huffman).

\section{Záver}

Všeobecne môžeme konštatovat', že drag sa v dramatickom umení primárne vyskytoval ako súčast’ komediálnych diel. Jednou z príčin môže byt’ hravá povaha charakteristická pre liminálnu fázu, ${ }^{53} \mathrm{v}$ ktorej sa umelci v dragu nachádzajú. Zároveň sa môžeme na problematiku pozerat' z pohl'adu androcentrickej heteronormatívnej spoločnosti - feminínni muži sú v rámci takejto spoločnosti často terčom posmechu, vnímaní ako komický objekt. V kontraste k tomu ženy, ktoré sa v rámci diela prezlečú do mužského prestrojenia, nadobudnú aspekty osobnej slobody a iné výhody, ktoré mužom poskytuje androcentrická spoločnost'. Tieto postavy už nie sú natol'ko signifikantne komické, dokonca môžu byt’ určitým spôsobom spoločensky desivé, ked’že ich existencia spochybňuje sociálne skonštruovanú autoritu mužov. Opisovaná prvoplánová komika dragu je však spravidla spojená s jednoduchšími formami dramatických diel, pre ktoré je charakteristická nízka presvedčivost’ prestrojenia, následkom čoho publikum a obvykle aj ostatné postavy hry evidujú, že ide o osobu prezlečenú do odevu charakteristického pre opačné pohlavie. Tieto prípady sú väčšinou rozličnými formami karikovania či parodovania osôb opačného pohlavia.

Pre diela vyššej kvality je typický dôraz na presvedčivost̉ dragu, v rámci moder-

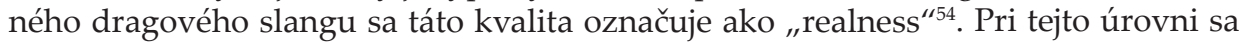
pozorovatelovi stráca z povedomia pôvodná identita osoby a úplne ju nahrádza jej alter ego. Ide o kvalitu, ktorá je značne subjektívna, závislá od schopností performera invokovat novú identitu prostredníctvom vonkajších a vnútorných prostriedkov a, samozrejme, od postoja pozorovatela, do akej miery je prístupný akceptovaniu takejto zmeny. Väčšina dramatických diel využíva ako súčast’ dragu vysokú presvedčivost' prestrojenia. $\mathrm{V}$ takýchto dielach nie sú obvykle postavy v dragu komickým objektom, ale skôr prostriedkom nastolenia komickej situácie. Dá sa povedat', že osoba v dragu nie je smiešna, pretože je v prestrojení, ale následkom udalostí, ktoré vd’aka tejto novej identite spôsobí.

Rodová performativita pomocou dragu má v dramatickom umení dlhú tradíciu. V európskom divadle sa vyskytovala minimálne od antických čias, dokonca ako

\footnotetext{
${ }^{51}$ V origináli The Adventures of Priscilla, Queen of the Desert. Austrália, 1994, réžia Stephan Elliott.

52 USA, 2005, réžia Duncan Tucker.

${ }^{53}$ SOUKUP, M. Základy kulturní antropologie. Červený Kostelec : Pavel Mervart, 2015, s. 196.

${ }^{54} \mathrm{~V}$ preklade presvedčivost'.
} 
esenciálny prvok drámy. Napriek historicko-kultúrnemu vývoju pretrval drag v dramatickom umení do dnešných čias, pričom z prostredia divadla plynulo prešiel aj do prostredia audiovizuálnej tvorby. Prejavy dragu v umení sa v dôsledku spoločenských zmien menili a dochádzalo k recipročnej výmene umeleckých prvkov medzi dramatickým umením a vonkajším svetom dragovej subkultúry. Rovnako prebiehalo v tejto oblasti aj vzájomné ovplyvňovanie divadelného prostredia a prostredia audiovizuálnej tvorby.

Doterajšie odborné a vedecké práce posudzovali drag v umení ako jednoliaty celok, bez ohladu na diferenciáciu jeho prejavov, pričom sa často sústred’ovali najmä na chronologický vývoj fenoménu, prípadne na otázky identity v dráme. Náčrt klasifikácie dragu v dramatickom umení, ktorý ponúka táto štúdia, má ambíciu napomôct' diferencovaniu jeho jednotlivých prejavov a prispiet' k d’alšiemu výskumu tejto problematiky.

\section{THE STATUS AND CLASSIFICATION OF DRAG IN THE WORKS OF DRAMATIC ART}

\section{Samuel BUCH}

In the history of the dramatic arts, it is a frequent phenomenon that characters of one sex are played by actors of the opposite sex. This phenomenon is found in cultures all over the world, with its roots probably lying in the spiritual practices of ancient cultures. The term drag, based on Polari language, is currently used to name this practice. In the light of the theories associated with rituals, the mask, and the concept of liminality, it can be stated that a person who is in drag is entering a liminal phase between the masculine and feminine worlds. This state allows the person to free himself/herself from gender stereotypes that limit the freedom and authenticity of personal expression. The intention of this paper is to present the historical development of drag and its function in human society and in the dramatic arts environment. The issue of drag in the dramatic arts has been mostly marginalised in scientific literature. The occasional works that have dealt with it have mostly not traced the distinct nature of individual manifestations, but have examined drag as an internally homogeneous phenomenon. Our work presents an internal classification of drag in the dramatic arts, with an ambition of better understanding the individual manifestations of drag, tracing their historical development and their socio-artistic function.

Text je výstupom projektu UGA II/1/2021 História a vývoj dragu na území Slovenska. Vznikol v rámci doktorandského štúdia ÚLUK FF UKF, školitel'ka Michaela Malíčková.

\section{LITERATÚRA}

BAKER, Paul. Fabulosa! The Story of Polari. London : Reaktion Books, 2020. 320 s. ISBN 978-178914-294-5.

BEARD, Mary. Ženy a moc. Bratislava : Inaque, 2020. 136 s. ISBN 978-80-8207-074-6.

BUTLER, Judith. Trampoty s rodom. Bratislava : Aspekt, 2014. 268 s. ISBN 978-80-8151-028-1. 
DOONAN, Simon. Drag. London : Laurence King Publishing, 2019. 240 s. ISBN 978-1-78627423-6.

ELIADE, Mircea. Mefisto a androgyn. Praha : Oikoymenh, 1997. 176 s. ISBN 80-86005-51-8.

ERBAN, Vít. Maska a tváŕ. Praha : Malá Skála, 2010. 246 s. ISBN 978-80-86776-09-5.

GALÁN, Juan Eslava. Láska a sex ve starém Řecku. Praha : Ikar, 2003. 232 s. ISBN 80-249-0244-3.

GARCIA, Lucas. Gender on Shakespeare's Stage: A Brief History. [online]. [cit. 5. 5. 2021]. Dostupné na internete: https://www.writerstheatre.org/blog/gender-shakespeares-stage-history/.

HALL, Jake - BIRKIN, Sofie - LI, Helen - HANS, Jasyot Singh. The Art of Drag. London : Nobrow, 2020. 133 s. ISBN 978-1-910620-71-7.

OBUCHOVÁ, L’ubica. Maska, kostým a lidové divadlo. Praha : Česká orientalistická společnost, 2001. 103 s. ISBN 80-902510-3-X.

POLÁK, Milan. Divadlo - jeho cesta dejinami. Bratislava : Perfekt, 2009. 166 s. ISBN 978-80-8046454-7.

SOUKUP, Martin. Základy kulturní antropologie. Červený Kostelec : Pavel Mervart, 2015. 273 s. ISBN 978-80-7465-186-1.

\author{
Samuel Buch \\ Ústav literárnej a umeleckej komunikácie \\ Filozofická fakulta \\ Univerzita Konštantína Filozofa v Nitre \\ Štefánikova 67 \\ 94974 Nitra \\ e-mail: samuel.buch@ukf.sk
}

